\title{
OPTIMUM REPLACEMENT POLICIES FOR A USED UNIT
}

\author{
Toshio Nakagawa \\ Meijo University
}

(Received January 16, 1979; Revised July 5, 1979)

\begin{abstract}
In many situations, it may be more economical to use a used unit than to do a new one. This paper considers an age replacement policy and a periodic replacement policy with minimal repair at failure for a used unit of age $\mathrm{x}$. We discuss optimum replacement policies which minimize the expected cost rates for a specified age $\mathrm{x}$. Further, we obtain an upper bound of an optimum time for an age replacement model and an optimum age of a used unit for a periodic replacement model when the replacement time is previously specified.
\end{abstract}

\section{Introduction}

Failure of a unit during actual operation is sometimes costly or dangerous. It is important to maintain the operating unit preventively before failure (e.g., inspection, overhaul, repair or replacement if needed). Many replacement and maintenance policies have been studied by many authors, e.g., $[1,5]$.

In the earlier contributions, almost all models discussed the optimum policies for a new unit, i.e., a new unit begins to operate at time 0 , and any units which operate successively are as good as new after repair or replacement. However, it may be better to operate a used unit than to do a new one in the case where the cost of a used unit is much less than a new one. Of course, this would depend on the performance of a used unit. Bhat [2] considered the replacement policy by a new unit at regular intervals of time and by a used unit at failure.

This paper considers two replacement models for a used unit of age $x$, which is replaced by one of identical units of the same age $x$ in the following policies [1]:

1. Age replacement; a unit is replaced at failure or at time $t_{0}$ after instal- 
lation, whichever occurs first.

2. Periodic replacement with minimal repair; a unit is replaced at times $\mathrm{kT}$ and undergoes a minimal repair at failure.

In this paper, we adopt the "expected cost rate" as the appropriate objective function, introducing the $\operatorname{cost}_{*} c_{*}(x)$ of a used unit of age $x$. We obtain optimum replacement times $t_{0}^{*}$ and $T^{*}$ which minimize the expected cost rates for a specified age $x$. Further, we obtain an upper bound of $t_{0}^{*}$ for model 1 , an optimum age $\mathrm{x}^{*}$ of a used unit for model 2 when $\mathrm{T}$ is specified, and moreover, we consider the modified model of periodic replacement suggested by Muth [4]. Several examples are presented.

\section{Age replacement policy}

Consider a used unit of age $x(0 \leq x<\infty)$ which is replaced by a unit of the same age upon failure. Assume that the failure time distribution of a new unit of the same type is an arbitrary $F(t)$ with finite mean $\lambda$. Then, the failure time distribution $F(t \mid x)$ of a used unit of age $x$ is, from [1]

$$
F(t \mid x) \equiv \frac{F(t+x)-F(x)}{\bar{F}(x)} \quad \text { for } F(x)<1, t \geq 0,
$$

where $\bar{F} \equiv 1-F$, and the mean residual life $\lambda(x)$ of the unit is

$$
\lambda(x) \equiv \int_{x}^{\infty} \bar{F}(t) d t / \bar{F}(x) \quad \text { for } F(x)<1
$$

Let $c_{0}(x)$ be the acquisition cost of a used unit of age $x$ and $c_{1}$ be all costs resulting from the failure. Then, the expected cost rate until failure is easily given by

$$
\begin{aligned}
C(x) & =\left[c_{0}(x)+c_{1}\right] / \lambda(x) \\
& =\frac{\left[c_{0}(x)+c_{1}\right] \bar{F}(x)}{\int_{x}^{\infty} \bar{F}(t) d t} \text { for } 0 \leq x<\infty .
\end{aligned}
$$

Next, consider an age replacement policy for a used unit of age $\mathrm{x}$, where $\mathrm{x}$ is previously specified. The unit is replaced at failure or is exchanged when it operates for a planned replacement time $t_{0}\left(0<t_{0} \leq \infty\right)$ without failure. Then, by a similar argument of obtaining (3), the expected cost rate is 
(4)

$$
\begin{aligned}
C\left(t_{0} ; x\right) & =\frac{c_{0}(x)+c_{1} F\left(t_{0} \mid x\right)}{\int_{0}^{t_{0}} \bar{F}(t+x) d t / \bar{F}(x)} \\
& =\frac{c_{0}(x) \bar{F}(x)+c_{1}\left[F\left(t_{0}+x\right)-F(x)\right]}{s_{0}^{t_{0}} \bar{F}(t+x) d t} .
\end{aligned}
$$
It is evident that $\lim _{t_{0} \rightarrow 0} C\left(t_{0} ; x\right)=\infty$ and $\lim _{t_{0} \rightarrow \infty} C\left(t_{0} ; x\right)=C(x)$ in (3). Further,

if $\mathrm{x}=0$ then $\mathrm{C}\left(\mathrm{t}_{0} ; 0\right)$ is coincident with that of $[1, \mathrm{p} .87]$, by replacing $c_{0}(x)$ and $c_{1}$ in (4) into $c_{2}$ and $c_{1}-c_{2}$, respectively.

We seek an optimum planned replacement time $t_{0}^{*}$ which minimizes $C\left(t_{0} ; x\right)$ in (4) for a fixed $x \geq 0$.

Suppose that the failure time distribution has a density $f$. Let $r(t) \equiv$ $f(t) / \bar{F}(t)$ be the failure rate and there exists the limit of $r(\infty) \equiv \lim _{t \rightarrow \infty} r(t)$. Then, differentiating $\mathrm{C}\left(\mathrm{t}_{0} ; \mathrm{x}\right)$ with respect to $\mathrm{t}_{0}$ and putting it equal to zero yield

$$
r\left(t_{0}+x\right) \int_{0}^{t_{0}} \bar{F}(t+x) d t-\left[F\left(t_{0}+x\right)-F(x)\right]=c_{0}(x) \bar{F}(x) / c_{1}
$$

Thus, if the failure rate $r(t)$ is monotonely increasing and

$$
r(\infty)>\frac{\left[1+c_{0}(x) / c_{1}\right] \bar{F}(x)}{\int_{x}^{\infty} \bar{F}(t) d t},
$$

i.e., $r(\infty)>C(x) / c_{1}$, then there exists a finite and unique $t_{0}^{*}$ which satisfies (5), and the expected cost rate is

$$
C\left(t_{0}^{*} ; x\right)=c_{1} r\left(t_{0}^{*}+x\right)
$$

Further, from the assumption that $r(t)$ is monotonely increasing, we easily have the inequality

$$
r\left(t_{0}+x\right) \int_{0}^{t} 0 \bar{F}(t+x) d t-\left[F\left(t_{0}+x\right)-F(x)\right]>r\left(t_{0}+x\right) \int_{x}^{\infty} \bar{F}(t) d t-\bar{F}(x) .
$$

Thus, if there exists a $\bar{t}_{0}$ satisfying $r\left(t_{0}+x\right)=c(x) / c_{1}$, i.e.,

$$
r\left(t_{0}+x\right) \int_{x}^{\infty} \bar{F}(t) d t-\bar{F}(x)=c_{0}(x) \bar{F}(x) / c_{1},
$$


then $t_{0}^{*}<\bar{t}_{0}$, which is the upper limit of $t_{0}^{*}$. In this case, it is easily shown that $\bar{t}_{0}$ is finite and unique since $r(\infty)>C(x) / c_{1}$ and $r(x)<1 / \lambda(x)<$ $\mathrm{C}(\mathrm{x}) / \mathrm{c}_{1}$.

If $r(t)$ is monotonely increasing and $r(\infty) \leq C(x) / c_{1}$, or $r(t)$ is nonincreasing, then $C^{-}\left(t_{0} ; x\right) \leq 0$ and hence, the optimum policy is $t_{0}^{*} \rightarrow \infty$.

Example 1.

Suppose that $\bar{F}(t)=(1+\alpha t) e^{-\alpha t}$. Then, the failure rate $r(t)$ is monotonely increasing with $r(0)=0$ and $r(\infty)=\alpha$. Thus, from the above results, if $c_{0}(x) \geq c_{1} /(1+\alpha x)$ then we should make no planned replacement. If $c_{0}(x)$ $<c_{1} /(1+\alpha x)$, we should adopt a planned replacement time $t_{0}^{*}$ which satisfies uniquely the following equation:

$$
\frac{\alpha t_{0}-\left(1-e^{-\alpha t_{0}}\right)}{1+\alpha\left(t_{0}+x\right)}=\frac{c_{0}(x)(1+\alpha x)}{c_{1}}
$$

and

$$
t_{0}^{*}+x<\frac{(1+\alpha x)\left[c_{0}(x)+c_{1}\right]}{\alpha\left[c_{1}-(1+\alpha x) c_{0}(x)\right]} .
$$

\section{Periodic replacement with minimal repair}

In the first model, we have assumed that a unit is replaced when it fails before a planned replacement time $t_{0}$. However, for more complex systems, it is costly to replace or overhaul systems for any intervening failures. We should repair failures as quickly as possible. From the point of view, model 2 has the following assumptions [1]:

(i) A unit is replaced or overhauled at times $\mathrm{kT}(\mathrm{k}=1,2, \ldots ; \mathrm{T}>0)$. (ii) A unit undergoes only minimal repair at failures between planned replacement, and the failure rate remains undisturbed by the minimal repair. For instance, a complex system fails for failure of a single component in the system. The failed component is replaced and the system begins to operate again. In this case, the system after the replacement has the same failure rate as before the replacement, due to the aging of the other components. Holland and McLean [3] gave a practical procedure for the policy to pieces of equipments, as examples of large motors and small electrical parts.

The expected cost rate for a used unit of age $\mathrm{x}$ is, by the method similar 
to $[1, \mathrm{p} .96]$, easily given by

$$
C(T ; x)=\left[c_{0}(x)+c_{2} \int_{x}^{T+x} r(t) d t\right] / T
$$

where $c_{2}$ is the cost of minimal repair.

Suppose that $\mathrm{x}$ is constant and previously specified. Then, differentiating $\mathrm{C}(\mathrm{T} ; \mathrm{x})$ with respect to $\mathrm{T}$ and setting it equal to zero, we have

$$
\int_{x}^{T+x}(t-x) d r(t)=c_{0}(x) / c_{2}
$$

Thus, if $r(t)$ is monotonely increasing and $\int_{0}^{\infty} t d r(t+x)>c_{0}(x) / c_{2}$, then there exists a $\mathrm{T}^{*}$ uniquely which minimizes $\mathrm{C}(\mathrm{T} ; \mathrm{x})$ in $(10)$, and the expected cost rate is

$$
\mathrm{C}\left(\mathrm{T}^{*} ; \mathrm{x}\right)=\mathrm{c}_{2} \mathrm{r}\left(\mathrm{T}^{*}+\mathrm{x}\right)
$$

Next, consider the problem that it is the most economical to use a unit of what is the age. Suppose that $\mathrm{x}$ is a variable and inversely, $\mathrm{T}$ is constant, and $c_{0}(x)$ is differentiable. Then, differeñtiating $C(T ; x)$ with respect to $x$ and setting it equal to zero imply

$$
r(T+x)-r(x)=-c_{0}^{\prime}(x) / c_{2}
$$

which is a necessary condition that a finite $\mathrm{x}$ minimizes $\mathrm{C}(\mathrm{T} ; \mathrm{x})$ for a fixed $\mathrm{T}$.

Example 2 .

Suppose that $c_{0}(x)=c_{0} e^{-\theta x}$ and $\bar{F}(t)=e^{-\alpha t^{m}}(m>1)$, which is a Weibull distribution with a shape parameter $m$, and the failure rate is $r(t)=m \alpha t^{m-1}$. Then, from (11), we have

$$
\mathrm{mT}(\mathrm{T}+\mathrm{x})^{\mathrm{m}-1}-(\mathrm{T}+\mathrm{x})^{\mathrm{m}}+\mathrm{x}^{\mathrm{m}}=\left[\mathrm{c}_{0} /\left(\alpha \mathrm{c}_{2}\right)\right] \mathrm{e}^{-\theta \mathrm{x}}
$$

which is monotonely increasing in $T$, taking the values from 0 to infinity.

Thus, an optimum $\mathrm{T}^{*}$ exists uniquely, which satisfies (14).

Further, from (13),

$$
\left[(T+x)^{m-1}-x^{m-1}\right] e^{\theta x}=\left[\left(c_{0} \theta\right) /\left(m a c_{2}\right)\right]
$$

which is monotonely increasing in $x$, taking the values from $T^{m-1}$ to infinity 
Thus,

(i) if $\mathrm{T}^{\mathrm{m}-1}<\left(\mathrm{c}_{0} \theta\right) /\left(\mathrm{mac}_{2}\right)$ then an optimum $\mathrm{x}^{*}$ exists uniquely, which satisfies (15),

(ii) if $T^{m-1} \geq\left(c_{0} \theta\right) /\left(m_{\alpha c}\right)$ then $x^{*}=0$, i.e., we should use a new unit.

Next, consider the particular case of $\mathrm{m}=2$. Then, from (14) and (15), the respective optimum times $\mathrm{T}^{*}$ and $\mathrm{x}^{*}$ are given by, explicitly,

$$
\mathrm{T}^{*}=\left[\frac{\mathrm{c}_{0}}{\alpha c_{2}} \mathrm{e}^{-\theta \mathrm{x}_{2}}\right]^{1 / 2}
$$

and for $\mathrm{T}<\left(\mathrm{c}_{0} \theta\right) /\left(2 \alpha c_{2}\right)$,

$$
x^{*}=\frac{1}{\theta} \log \frac{c_{0} \theta}{2 \alpha c_{2} T}
$$

Further, suppose that both $\mathrm{x}$ and $\mathrm{T}$ are variables. Then, from (14) and (15),

$$
\begin{aligned}
& \alpha c_{2} T^{2}=c_{0} e^{-\theta x} \\
& 2 \alpha c_{2} T=c_{0} \theta e^{--\theta x} .
\end{aligned}
$$

Thus, $\mathrm{T}^{*}=2 / \theta$ and

(i) if $4 \alpha c_{2} \geq c_{0} \theta^{2}$ then $x^{*}=0$,

(ii) if $4 \alpha c_{2}<c_{0} \theta^{2}$ then $x^{*}=\frac{1}{\theta} \log \frac{c_{0} \theta^{2}}{4 \alpha c_{2}}$.

We give the numerical examples where $c_{0} / c_{2}=5, m=2$, and $1 / \alpha=10,000$. Table 1 shows the optimum replacement time $\mathrm{T}^{*}$ of a used unit of age $\mathrm{x}$ and the optimum age $\mathrm{x}^{*}$ for a planned replacement time $\mathrm{T}$, when $1 / \theta=50$. Further, Table 2 shows the optimum replacement time $\mathrm{T}^{*}$ and the optimum age $\mathrm{x}^{*}$, both of which are variables, for a discount factor $\theta$. It is noted that, in particular case of $1 / \theta=50$, the results coincide with those of Table 1 .

Finally, consider the following modification of periodic replacement with minimal repair suggested by Muth [4]:

(i) A unit is replaced when it fails for the first time after time $\mathrm{T}(\mathrm{T} \geq 0)$. (ii) A unit undergoes only minimal repair at failure before time $\mathrm{T}$. Then, the expected cost of a used unit of age $x$ is easily given by

$$
C(T ; x)=\frac{c_{0}(x)+c_{1}+c_{2} \int_{x}^{T+x} r(t) d t}{T+\lambda(T+x)},
$$


Table 1. Body of the table gives the optimum replacement time $\mathrm{T}^{*}$ for the age $x$ of a used unit and the optimum age $x^{*}$ of a used unit for a planned replacement time $\mathrm{T}$, where $\mathrm{c}_{0} / \mathrm{c}_{2}=5, \mathrm{~m}=2,1 / \alpha=10,000$, and $1 / \theta=$ 50 .

\begin{tabular}{rc|cc}
\hline $\begin{array}{c}\text { age of } \\
\text { unit } \mathrm{x}\end{array}$ & $\begin{array}{c}\text { optimum replacement } \\
\text { time T* }\end{array}$ & $\begin{array}{c}\text { replacement } \\
\text { time T }\end{array}$ & $\begin{array}{c}\text { optimum age } \\
\mathrm{x}^{*}\end{array}$ \\
\hline 0 & 224 & 20 & 161 \\
10 & 202 & 40 & 116 \\
20 & 183 & 60 & 106 \\
40 & 150 & 80 & 92 \\
60 & 123 & 100 & 80 \\
80 & 100 & 120 & 71 \\
100 & 82 & 140 & 64 \\
120 & 67 & 160 & 57 \\
140 & 55 & 200 & 46 \\
\hline
\end{tabular}

Table 2. Body of the table gives the optimum replacement time $\mathrm{T}^{*}$ and the optimum age $x^{*}$ of a used unit for a discount factor $1 / \theta$.

\begin{tabular}{c|cc}
$\begin{array}{c}\text { discount factor } \\
1 / \theta\end{array}$ & $\begin{array}{r}\text { optimum replacement } \\
\text { time } \mathrm{T}^{*}\end{array}$ & $\begin{array}{c}\text { optimum age } \\
\mathrm{x}^{*}\end{array}$ \\
\hline 20 & 40 & 69 \\
40 & 80 & 82 \\
50 & 100 & 80 \\
60 & 120 & 75 \\
80 & 160 & 54 \\
100 & 200 & 22 \\
120 & 240 & 0 \\
\hline
\end{tabular}


where $c_{1}$ is the cost suffered for the failure and $\lambda(x)$ is defined in (2). It is evident that $\mathrm{C}(0 ; \mathrm{x})=\mathrm{C}(\mathrm{x})$ in (3).

Suppose that $x$ is previously specified. Then, differentiating $C(T ; x)$ with respect to $T$ and setting it equal to zero, we have

$$
\frac{T}{\lambda(T+x)}-\int_{x}^{T+x} r(t) d t=\frac{c_{0}(x)+c_{1}-c_{2}}{c_{2}} .
$$

Assume that $c_{0}(x)+c_{1}>c_{2}$ and $r(t)$ is monotonely increasing. Then, if a solution to (17) exists, it is unique. For, denoting the left side of (17) by $h(T)$ and differentiating it with respect to $T$, we have

$$
h^{\prime}(T)=\left[\frac{1}{\lambda(T+x)}-r(T+x)\right]\left[1+\frac{T}{\lambda(T+x)}\right]>0,
$$

since $1 / \lambda(T+x)>r(T+x)$ by the assumptions. If $c_{0}(x)+c_{1} \leq c_{2}$ then $C^{\prime}(T ; x)$ $\leq 0$, i.e., we should replace a unit only at failure.

\section{Conclusions}

We have considered two replacement models of a used unit and obtained the optimum policy which minimizes the expected cost rate of each model. In the example, we have obtained both optimum replacement time and optimum age of a used unit, when both are variables. These results would be useful in practical cases such that we have to serve a used unit or it is more economical to adopt a used unit than a new one.

In the examples, we have only considered two simple functions of $c_{0}(x)$, however, we could apply to more general functions of $c_{0}(x), e . g ., c_{0}(x)=$ $c_{0} \exp \left(-\theta x^{\beta}\right)(\beta \geq 1)$ and

$$
c_{0}(x)= \begin{cases}c_{0}-\theta x & \text { for } x<c_{0} / \theta, \\ 0 & \text { otherwise. }\end{cases}
$$

Moreover, if we introduce a net resale value $e_{0}(x)$ of a used unit of age $x$, which is exchanged at a planned replacement, the equations (4) and (10) are rewritten as, respectively,

$$
\begin{aligned}
& C\left(t_{0} ; x\right)=\frac{c_{0}(x) \bar{F}(x)-e_{0}\left(t_{0}+x\right) \bar{F}\left(t_{0}+x\right)+c_{1}\left[F\left(t_{0}+x\right)-F(x)\right]}{\int_{0}^{t_{0}} \bar{F}(t+x) d t}, \\
& C(T ; x)=\frac{c_{0}(x)-e_{0}(T+x)+c_{2} J_{x}^{T+x} r(t) d t}{T} .
\end{aligned}
$$


Further, we can consider other maintenance policies of a used unit, e.g., a preventive maintenance policy [5] and a block replacement policy [1, p. 95]. The discussions in this paper could be applied to such policies.

\title{
References
}

[1] Barlow, R.E. and Proschan, F.: Mathematical The ory of Re Ziabizity. John Wiley \& Sons, New York, 1965.

[2] Bhat, B.R.: Used Item Replacement Policy. J.App Z. Prob., Vol. 6, No. 2 (1969), 309-318.

[3] Holland, C.W. and McLean, R.A.: Applications of Replacement Theory. AIIE Trans., Vol. 7, No. 1 (1975), 42-47.

[4] Muth, E.J.: An Optimal Decision Rule for Repair vs Replacement. IEEE Trans. on Reliability, Vo1. R-26, No. 3 (1977), 179-181.

[5] Nakagawa, T.: Optimum Preventive Maintenance Policies for Repairable Systems. IEEE Trans. on Re liability, Vol. R-26, No. 3 (1977), 168-173.

\author{
Toshio NAKAGAWA \\ Department of Mathematics \\ Meijo University \\ Tenpaku-cho, Tenpaku-ku \\ Nagoya, 468, Japan
}




\section{中古ユニットに対する最適取替方策}

名城大学中川覃夫

動作中のンステムの故障はしばしば多額の費用とときには危険な状態を招くことがある。この場合， 故障する前に何時ンステムを取替えるかを決めることは重要であり，いくつかの取替方策が考察され ている。

ここでは， $\mathrm{x}$ 時間使用した (年令 $\mathrm{x}$ という) 中古ユニットの取替方策を考える。実際の場合, 新品 を使用するより中古品を使った場合が得策な場合も多いし，何らかの事情で中古品を使わなければな らない場合ああるう。このような場合、取替方策を講じることは新品の部品より重要であるう。ここ では，次の取替方策をもつ2つのモデルを考える。

1. 年令による取替; ユニットは故障または稼動開始後 $\mathrm{t}_{\mathrm{o}}$ 時間に取替えられる。

2. 小修理を伴う定期取替；ユニットは一定時間間隔 $\mathrm{T} て ゙$ 取替えられ，その間に故障した場合は小修 理が行われる。

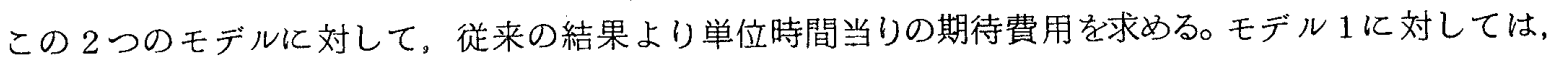
年令 $\mathrm{x}$ が与えられたとき, 期待費用を最小にする最適方策について考察する。ある条件のもとで。最 適取替時間 $\mathrm{t}_{0}^{*}$ が方程式の唯一の解として求められることが示される。この場合, 取替時間の上限も示 される。

モデル2に対しては, 年令 $\mathrm{x}$ をえたときの最適取替時間 $\mathrm{T}^{*}$ と, 逆に, 取替時間 $\mathrm{T}$ をえたときの 中古ユニットの最適年令 $\mathrm{x}^{*}$ について考察する。前者の場合，ある条件のもとで，最適取替時間が方程 式の唯一の解として求められる。例で，ユニットの故障分布とそれの取得費用関数を具体的に与え， 両方がともに変数のとき, 期待費用を最小にする各々の最適時間を求め, 数值例も示される。更に, これを補正したモデルで，一定時間 Tで取替えるのでなく，その後初めて故障したとき取替える場合 を考える。このモデルほ対しても，前と同様な方法で，最適方策について議論する。

ここで得られた結果は従来の新品同様のユニットの取替問題で得られている結果の拡張になってい る。

最後に, 中古ユニットの取得費用関数と再び転売する費用を考慮した場合が簡単に述べられる。 